\title{
Impact of Agricultural Drought Resilience on the Welfare of Smallholder Livestock Farming Households in the Northern Cape Province of South Africa
}

\author{
Ringetani Matlou ${ }^{1}$, Yonas T. Bahta ${ }^{1, * \mathbb{D}}$, Enoch Owusu-Sekyere ${ }^{1,2} \mathbb{D}$ and Henry Jordaan ${ }^{1} \mathbb{D}$ \\ 1 Department of Agricultural Economics, University of the Free State, P.O. Box 339, \\ Bloemfontein 9300, South Africa; ringetani@urban-econ.com (R.M.); enoch.owusu.sekyere@slu.se (E.O.-S.); \\ JordaanH@ufs.ac.za (H.J.) \\ 2 Department of Economics, Swedish University of Agricultural Sciences, P.O. Box 7013, \\ 75007 Uppsala, Sweden \\ * Correspondence: BahtaY@ufs.ac.za; Tel.: +27-514-019-050
}

check for

updates

Citation: Matlou, R.; Bahta, Y.T.; Owusu-Sekyere, E.; Jordaan, H. Impact of Agricultural Drought Resilience on the Welfare of Smallholder Livestock Farming Households in the Northern Cape Province of South Africa. Land 2021 10, 562. https://doi.org/10.3390/ land 10060562

Academic Editors: Sheona Shackleton, Gladman Thondhlana, Sheunesu Ruwanza, Elandrie Davoren, Staffan Rosell, Andrea Belgrano, Regina Lindborg, Ken Findlay and James Gambiza

Received: 22 March 2021

Accepted: 24 May 2021

Published: 27 May 2021

Publisher's Note: MDPI stays neutral with regard to jurisdictional claims in published maps and institutional affiliations.

Copyright: (c) 2021 by the authors. Licensee MDPI, Basel, Switzerland. This article is an open access article distributed under the terms and conditions of the Creative Commons Attribution (CC BY) license (https:/ / creativecommons.org/licenses/by/ $4.0 /)$.

\begin{abstract}
Recurring agricultural droughts are of concern to smallholder livestock farmers in SubSaharan Africa. This study determined the impact of agricultural drought resilience on smallholder livestock farming households' welfare in the Frances Baard District Municipality (FBDM), in Northern Cape Province of South Africa. Interviews, more specifically survey interviews, were conducted with 207 smallholder livestock farmers. We used compensation variation, resilience index and linear regression models to analyse the data. The findings indicate that smallholder farmers who received drought relief support saw an improvement in their welfare. However, the welfare improvements varied across respondents and different gender categories, with males having higher welfare improvements relative to females. The study also found that economic capital, social capital, human capital and natural capital substantially affected the welfare of smallholder farmers. Furthermore, the study revealed that the smallholder farmers had a moderate agricultural drought resilience index, but low natural resilience capital. The study recommends that governments and non-governmental policymakers aiming to improve the welfare of smallholder farmers should focus on building their economic, social, human and capital resource bases. In this way, the smallholder farmers will be resilient in a time of climatic shock.
\end{abstract}

Keywords: resilience; welfare; compensation variation; agricultural drought; agricultural drought index

\section{Introduction}

Globally, climate change significantly impacts food production, including livestock production. Production may be affected in several ways, such as increased operational and input costs (e.g., feed, medication and disease), climate change (e.g., agricultural drought and temperature increases), a rise in the price of animal housing (cooling systems) and fodder quality and quantity [1]. As stated by the FAO [2] and Wilhite, Sivakumar and Pulwarty [3], the period, intensity and occurrence of droughts could increase due to climate change.

With the effects of agricultural drought rising notably, there is pressure on natural resource sustainability and welfare. Africa in general and South Africa in particular are the most vulnerable regions to drought [2]. Drought periods affect the agricultural sector the most compared to other sectors (mining, manufacturing, construction, trade, transport, finance and community service) [3]. In most countries, agricultural production relies highly on weather conditions and water availability. As drought impacts livestock, it can result in poor productivity, decreased fertility, poor animal health and a rise in livestock mortality [4]. The livestock sector employs one billion poor people globally and contributes $17 \%$ of kilocalories and $33 \%$ of protein consumed [5]. 
According to Maltou and Bahta [6], the 2015/2016 agricultural drought in South Africa resulted from strong El Niño conditions, similar to those experienced in 1933 and 1982. El Niño is commonly linked to droughts in southern Africa and has had devastating impacts on the lives and livelihoods of farmers and herders. An estimated 40 million people have been affected by drought in southern Africa with a cereal deficit of 9.3 million tonnes recorded at the end of the 2015/2016 cropping season $[7,8]$. The high regional deficit raised staple food prices and constrained the already limited purchasing power of vulnerable families. More than 643,000 livestock deaths were reported in five countries alone due to lack of feed and water and disease outbreak in southern Africa. The income sources of many households diminished due to loss of crops, livestock, labour, trading and self-employment activities [7,8]. During 2015, agricultural production in South Africa declined by $8.4 \%$ due to drought. The livestock industry, for example, had a $15 \%$ reduction in the national herd stock due to the drought [9].

Recurrent agricultural drought remains a challenge for smallholder farmers due to the unavailability of resources and because their household food security relies on their own production [9]. Various constraints undermine South African smallholder farmers' ability to produce adequate output. Constraints include socioeconomic, institutional, economic development and community factors [10,11]. The Department of Agriculture, Forestry, and Fisheries (DAFF) [10], Mpandeli and Maponya [11] and Khoza et al. [12] highlighted that smallholder farmers face various challenges that impede their growth and ability to contribute effectively relative to commercial farmers. Some of the challenges they face include lack of access to land, poor physical and institutional infrastructure, lack of assets, lack of information, lack of education and smaller farm size. Most smallholder farmers are located in rural areas where the lack of both physical and institutional infrastructure limits their expansion and access to information. Lack of access to proper roads, for example, limits farmers' ability to transport inputs and produce to and from markets. The infrastructure is poor, and the markets for agricultural inputs and outputs are often missing and unreliable for smallholder farmers. High transaction cost is also one of the major factors constraining growth of smallholder farmers and is largely attributed to poor infrastructure. Lack of human capital has also been found to be a serious constraint for smallholder farmers. They are often illiterate with poor technological skills, which can be serious obstacles in accessing useful formal institutions where technological knowledge is disseminated. The majority of smallholder farmers are not capacitated with financial and marketing skills and are unable to meet the quality standards set by markets. Lack of production knowledge leads to lower quality in production. As a result of low endowment in production factors such as land, water and capital assets, the majority of smallholder farmers produce low quantities of products that are of poor quality, which leads to their products being neglected by output markets $[11,12]$. Furthermore, due to climatic variability, farmers are subject to unpredictable rainfall and other weather-related problems.

Agricultural systems are complex social ecological systems that are substantially affected and increasingly threatened by various hazards, such as climate change, and are thus often assessed with respect to their resilience [13]. With growing concern about climate and environmental changes as well as increases in social, economic and political upheavals, the concept of resilience has become popular across a range of sectors as a way to understand and respond to our surprise-riddled world [14].

There are different definitions for resilience, but they have shared characteristics [15-17]. Nearly all definitions stress the common elements of resilience, which include ability, mitigation, adaptation, coping, recovery, withstanding shocks, resistance and bouncing back against shocks. Banda et al. [18] highlighted that increasingly common weather-related shocks add to the many challenges that farmers face, including declining soil fertility, increasing population and rising prices of farm inputs, even as farm output prices remain low. Of all the sectors of the economy affected by these disasters, agriculture is the most severely affected. Prolonged dry spells, droughts and floods present particularly problematic challenges because they are exogenous shocks beyond the influence of small- 
holder producers. For example, the Malawi Vulnerability Assessment Committee (MVAC) reported that nearly $10 \%$ of the Malawi population (approximately 1.1 million people) were food insecure between the months of October 2013 and March 2014. This was partly attributed to poor harvests that some parts of the country registered due to unfavourable weather conditions. It is therefore important for farmers to increase their resilience to the adverse effects of these shocks. If they become more resilient, they will be better able to deal with challenges that come their way without a significant loss in household welfare.

Rojas-Downing et al. [5] reviewed the global impact of climate change on livestock production, the contribution of livestock production to climate change and specific climate change adoption and mitigation strategies in the livestock sector. They found that livestock production is limited by climate variability and the livestock sector contributes to $14.5 \%$ of global greenhouse gas (GHG) emissions, driving further climate change. Consequently, the livestock sector will be a key player in the mitigation of GHG emissions and improving global food security. Venter [19] reviewed the application and relevance of resilience to understand and manage ecosystem change and enhance the capacity of land users to adapt to droughts. The author found that research on resilience and thresholds in relation to drought needs to be long term, flexible and opportunistic in order to capture slow and stochastic processes. Sallu et al. [20] explored the resilience and vulnerability of livelihoods within two different social-ecological dryland contexts using a survey and livelihood trajectory approach. They identified accumulator, diversifier and dependent households as well as the ways in which households move among these categories. More resilient livelihood trajectories can be achieved if the important role of formal and informal institutions is recognised.

Jordaan [21] assessed drought risk reduction using indicators and found that a national policy dealing with all drought-related issues should be implemented using a holistic approach. Banda et al. [18] identified factors that affect resilience to drought among smallholder farmers and used those factors to determine the effect of drought resilience on the welfare of farming households via the drought resilience index and stochastic frontier production function. They reported that the majority of smallholder farmers were not resilient to drought and factors such as age of the household head, size of the farm family, landholding size and the number of immediate family members living outside the household affected their drought resilience. They also found a positive correlation between resilience and improved household welfare. Mdungela et al. [22] determined the factors that influenced communal farmers' choice of coping strategies using survey and multinomial probit model. Thy identified the three main coping strategies used by farmers: irrigation, diversification and drought resistant crops/breeds.

To the best of our knowledge, very few studies specifically focused on the welfare of smallholder livestock farming households and how agricultural drought resilience influences farmers' welfare. Therefore, this study determined how agricultural drought resilience capitals affected smallholder livestock farmers' welfare in the Frances Baard District Municipality, located in the Northern Cape Province of South Africa. Specifically, we examined how different sustainable livelihood capitals influenced the welfare of both men and women. We employed an amended Sustainable Livelihood Framework (SLF) in our analysis. This study incorporated the Agricultural Drought Resilience capitals as independent variables for explaining welfare changes among farmers. The novelty of this paper lies in the incorporation of welfare assessment of smallholder farmers using a rigorous welfare measurement approach (i.e., compensation variation (CV)). Unlike previous studies [19-22] which focused mainly on the vulnerability and capacity of land users to adapt to droughts $[19,20]$ as well as determinants of choice of coping strategies [21,22], this study innovates by using a non-parametric approach (i.e., CV), which allowed us to assess income losses and gains needed to restore smallholder farming households back to their living conditions prior to drought. In addition, this study adds to existing knowledge by finding which of the sustainable livelihood capital resources can help smallholder bounce back quickly from drought shock. This study's findings could help government and policy- 
makers to develop suitable policies and mitigation strategies to build the resilience and welfare of smallholder livestock farmers against prolonged agricultural drought.

The remainder of the article is structured as follows. Section 2 presents the materials and methods. Section 3 presents the results. Section 4 presents the discussion of the results. Section 5 outlines the conclusion and policy implications.

\section{Materials and Methods}

\subsection{Study Area}

The study was conducted in the Northern Cape Province of South Africa. This province is by far the largest province located in the northwestern corner of South Africa. The land area of the province is $372,889 \mathrm{~km}^{2}$, which account for $30.5 \%$ of the total land area of South Africa [23]. The province is classified as semi-desert and desert areas, and it is normally a hot and dry region. The Northern Cape climate is characterised by hot summers (between 34 and $40^{\circ} \mathrm{C}$ ) and cold winters (below $0{ }^{\circ} \mathrm{C}$ nightfall temperatures and frost). Coupled with low rainfall (mean annual precipitation of $200 \mathrm{~mm}$ ), the climate is dry and relentless.

The Northern Cape Province has five district municipalities: Frances Baard $\left(12,800 \mathrm{~km}^{2}\right)$, John Taolo Gaetsewe $\left(27,300 \mathrm{~km}^{2}\right)$, Namakwa $\left(126,900 \mathrm{~km}^{2}\right)$, Pixley Ka Seme $\left(103,500 \mathrm{~km}^{2}\right)$ and ZF Mgcawu (102,500 km²) [23]. The study was conducted in Frances Baard District Municipality, which is divided into four local municipalities: Dikgatlong $\left(2377.6 \mathrm{~km}^{2}\right)$, Magareng $\left(1541.6 \mathrm{~km}^{2}\right)$, Phokwane $\left(833.9 \mathrm{~km}^{2}\right)$ and Sol Plaatje $\left(1877.1 \mathrm{~km}^{2}\right)$ (see Figure 1) [23].

A variety of agricultural production occurs in the Northern Cape Province of South Africa due to the vast difference in climate among the district municipalities. Livestock production remains the leading enterprise, with $\sim 75 \%$ of agricultural households farming with animals only [24]. In South Africa, the Northern Cape produces approximately $4 \%$ of the country's cattle, $24 \%$ of the sheep, $7 \%$ of the goats and $1.4 \%$ of the chickens (Department of Agriculture, Forestry and Fisheries (DAFF) [25].

\subsection{Conceptual Framework}

This study used the Sustainable Livelihood Framework (SLF) of the Department for International Development (DFID) [26], as presented in Figure 2, with amendments. SLF was used because it incorporates multiple capitals, which allowed for evidence-based interventions and calculation of resilience index. SLF is also practically suitable for conditions where there are limited resources to support development interventions [26-28]. SLF is a tool to improve the understanding of smallholder farmers' livelihoods [26]. Five principal capitals including human, social, natural, financial and physical capitals are suggested in SLF as important to livelihoods [27,29]. The capitals are required for livelihoods of smallholder livestock farmers to build resilience and recover from "stress and shocks".

However, in this study, SLF was slightly amended by categorising the five capitals into four resilience capitals: human, social, natural and economic capitals. Specifically, physical and financial capitals were pooled together to form economic capital. This amendment was based on the arguments by Keil et al. [15] and Scoones [29] that a distinction between physical and financial assets is often hard to make, mainly when the resource is easily traded; hence, they pooled financial and physical capital into one integrated capital, economic capital. Thus, for this study, there were four capitals essential for smallholder livestock farmers to enhance their resilience to agricultural drought. These capitals were crucial factors for smallholder livestock farmers in Sub-Saharan Africa and South Africa [30]. The strengths of these capitals were hypothesised to impact smallholder livestock farmers' welfare.

This framework considered that the extent of resilience-building by a household varied from other households and that various factors determined this difference. As depicted, smallholder livestock farmer's welfare was influenced by the capital resources available to the farmers in times of drought and these capitals defined by their indices were used to compute the agricultural drought resilience index. Human capital involved education, health, knowledge, skills and the capacity to work. Information sharing and 
social learning within and between networks of smallholder livestock farmers formed social capital. Capital given by local resource endowments and the outcome of human action comprised natural capital. All resources for production and processing, personal assets and services, cash, credit and saving (economic capital) are vital to enhance the resilience of smallholder farmers [31-34].



Figure 1. Frances Baard District Municipality Map. Source: Frances Baard District Municipality [23]. 


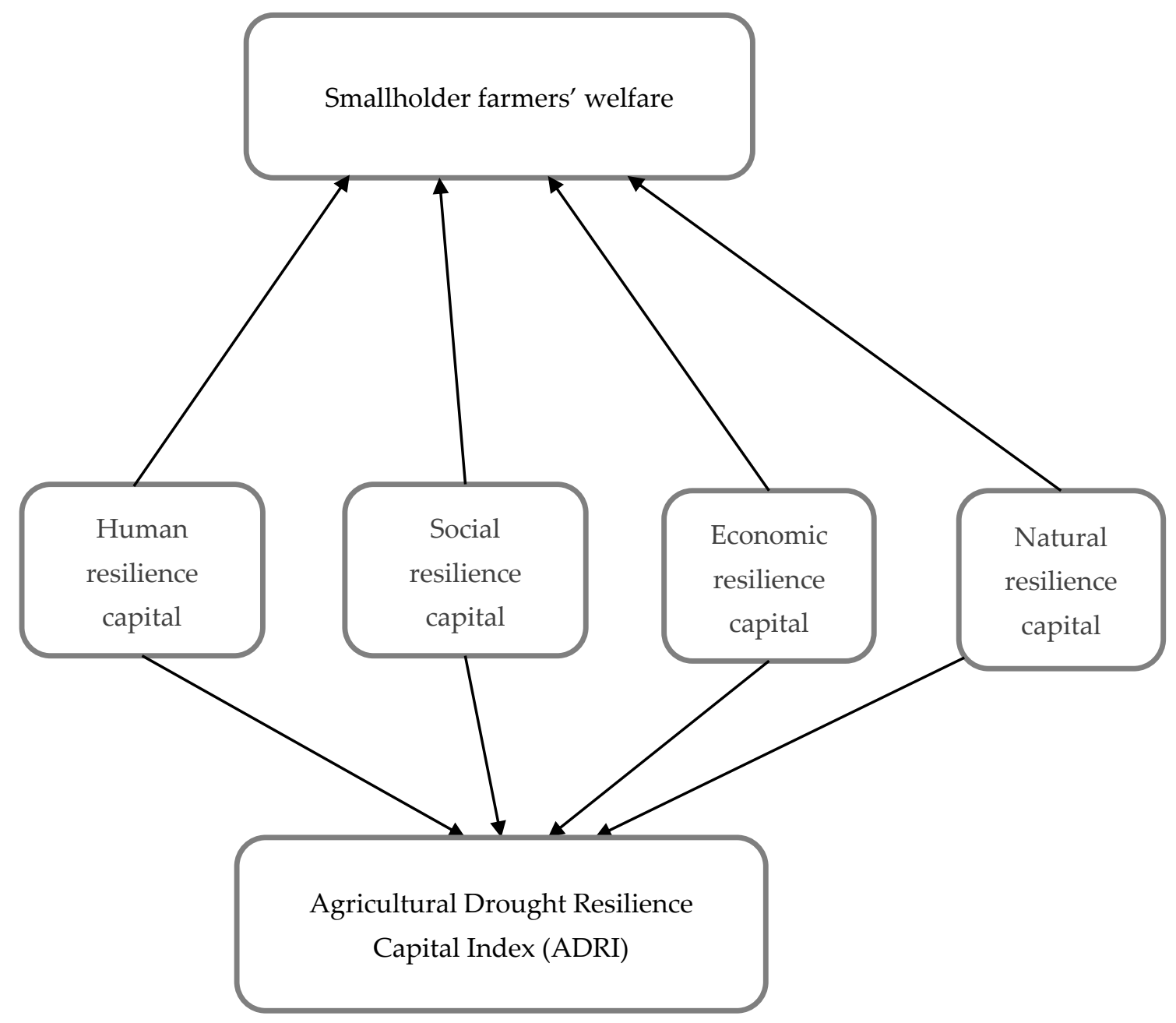

Figure 2. Analytical framework adapted and amended from the Sustainable Livelihood Framework (SLF). Source: Author's compilation.

\subsection{Data and Sampling}

Primary data were collected from smallholder livestock farmers in the Northern Cape Province of South Africa using a structured questionnaire. The survey was conducted using a multi-stage sampling technique. In the first stage, the Northern Cape Province was chosen purposively because it represents the main livestock-producing province in South Africa. Additionally, the South African government has declared the province a disaster area $[35,36]$. The second stage of the sampling involved the simple random selection of The Frances Baard District Municipality (FBDM) using balloting. Within FBDM, four municipalities, namely, Phokwane, Magareng, Sol Plaatjie and Dikgatlong, were purposively selected for sampling as the main livestock-producing municipalities. Finally, the list of smallholder farmers identified and assisted during the 2015/2016 production season was used as the sample frame. According to the Department of Agriculture Northern Cape [37], there are 868 smallholder livestock farming units in the FBDM that were assisted by the four local municipalities. Based on a simple random sampling formula [38,39], 207 smallholder livestock farmers were selected from the 868 assisted farmers.

Face-to-face interviews were conducted with the selected respondents between July and September 2018 to complete questionnaires. Specifically, the questionnaire consisted of both open- and closed-ended questions. The first section of the questionnaire solicited information on socioeconomic characteristics of farmers such as age, gender, household sizes, marital status, education, years of farming, source of funding, etc. The second section of the questionnaire solicited information on types of resources available to the farmers, 
e.g., natural capital items such as land ownership, land size, access to water, etc. The third section contained questions on production and farming activities (e.g., number of livestock and feed availability). The fourth and fifth sections solicited information on household consumption, expenditure and resource endowment (e.g., number of tractors, farm trucks, etc.). The final section solicited information on drought, resilience and knowledge of agricultural drought.

\subsection{Agricultural Drought Resilience Indices (ADRI)}

The calculation of the agricultural drought resilience indices (ADRI) followed the resilience framework and scale by Walsh-Dilley et al. [40]. The calculation of the ADRI encompassed the following steps: (i) selection of resilience indicators; (ii) normalisation of the selected indicators; (iii) generation of scales and weights; and (iv) aggregation of final resilience index [40]. The weights for each resilience indicator were based on principal component analysis (PCA). Based on PCA, we allocated weights according to the percentage variance explained by each indicator. We further subjected the weights from PCA to expert judgment. The weighting was performed to explore any possible correlation among the selected indicators as well as to deal with overlapping factors [41]. Four resilience indicators consisting of human, social, economic and natural capitals were identified. Each resilience capital (RI) was calculated as the summation of indicators defining the capitals by their respective weights generated from the PCA and specified as:

$$
R I_{\mathcal{C}}=\sum_{c=1}^{S} w g t_{i} * \text { indicators }_{i}
$$

$R I$ denotes the individual resilience capital index for $\mathrm{S}$ (i.e., human capital (HC), social capital (SC), economic capital (EC) or natural capital (NC) and $w t g_{i}$ denotes the weight for each indicator for a given capital. The variables defining each capital are represented by indicators ${ }_{i}$. The total ADRI was the summation of the HC, SC, EC and NC computed by Equation (1). In the interest of brevity, details of the variables defining each capital are not included in this paper; however, they are available upon request and in agreement with the data usage policy. The human capital measured in this study related to the farmer's knowledge, experience, skills, competencies and other farmer characteristics relevant to livestock farming [31,42]. The social capital comprised variables relating to the farmer's social networks such as membership in farmer associations and connections with the municipal agricultural department, families and friends that could be relied on in times of drought [32]. The economic capital comprised all production resources and farmers' assets such as tractors, trucks, radio, stock, etc. Finally, the natural capital was generated from natural resource stock.

\subsection{Calculation of Smallholder Farmers' Household Welfare}

Smallholder farmers' household welfare calculations followed the compensation variation (CV) approach [43]. CV is a non-parametric approach, which measures income losses and gains needed to restore farming households back to their living conditions prior to drought $[43,44]$. The welfare of farming households was assumed to be affected by drought, which shifted the households from their original welfare state. A given farming household's welfare gain was dependent on the amount of drought relief support received from the municipality. In accordance with economic theory, the study hypothesised that smallholder households that received drought relief support would have experienced improved welfare gains compared to those that had not received drought relief. Similarly, since the amount of support differed across farmers depending on the degree of loss incurred due to drought, we assumed that welfare differed across farmers. The CV was expressed as:

$$
\frac{\Delta w_{n}}{Z_{o n}}=\frac{\Delta p^{s}}{p_{o}^{s}} \operatorname{Pr}_{n}-\frac{\Delta p^{v}}{p_{o}^{v}} C m_{n}
$$


We denote the first-order approximation of smallholder farmer $n$ 's welfare change that arose from drought by $\Delta W_{n} ; Z_{O n}$ denotes the income of smallholder farmer $n$ before the drought; the price at which production was valued before drought is denoted as $p^{s} o$; $p^{v} o$ is the price at which consumption was valued before drought; $\operatorname{Pr}_{n}$ denotes livestock and other production value of farming household $n$; and $\mathrm{Cm}_{n}$ denotes consumption value for smallholder farmer $n$ 's household. Equation (2) estimated the post-drought response by smallholder farmers utilising their consumption and production choice. To take into account variations in welfare gains, we re-specified Equation (2) as:

$$
\frac{\Delta W_{i}}{Z_{o_{n}}}=0.1\left(P_{r_{n}}-C_{m_{n}}\right)
$$

Based on Equation (3), the expectation was that a smallholder farmer who benefited from drought relief was expected to gain welfare improvement, and the level of welfare improvement was dependent on the amount of drought relief (DR) support as well as resilient capitals, namely HC, SC, EC and NC. Those without drought relief would have experienced welfare loss. The CV approach is mostly employed for evaluating the impact of price changes. However, we used it because drought influenced food prices and household consumption. The computed household welfare estimate was used as the dependent variable in the regression model specified as Equation (4). The regression model was specified due to the continuous nature of the dependent variable.

$$
W_{n}=\text { gender }_{n}+H C_{n}+S C_{n}+E C_{n}+N C_{n}+D R_{n}+\mu_{n}
$$

where $W i$ is the estimated welfare change of farmers in percentage; DR denotes drought relief; and other variables are defined above. Robust standard errors were computed to account for any possible heteroscedasticity issues.

\section{Results}

\subsection{Socioeconomic Characteristics of the Respondents}

Table 1 presents the respondents' socioeconomic characteristics. Most of the respondents were male, which implies that livestock farming is male-dominated (Table 1). Approximately $67 \%$ of the respondents were married. About $20 \%$ of the smallholder livestock farmers were single, $11 \%$ widowed and $2 \%$ divorced. Formally employed farming household heads may have been resilient to agricultural drought. Overall, $144(70 \%)$ respondents reported farming as their main occupation (full time farmers), while $63(30 \%)$ farmers reported that farming was their second occupation (part-time farmers). Regarding outside the farm employment, only $2 \%$ of the respondents were self-employed. Overall, $38 \%$ of the respondents were pensioners who reported using their pension money for farm operations, even during drought periods. Funding remains imperative for any farming business. Smallholder farmers did not have access to credit. Fifty per cent of the respondents indicated that they used their family savings to conduct their farm operations; this could have led to farmers becoming more vulnerable during agricultural drought. In comparison, $45 \%$ used other means of funding such as monthly salaries, pension, livestock sales and money from piece jobs. The rest of the respondents used other sources (3\%) and borrowed from various sources.

Table 2 presents the descriptive statistics of the respondents. The average age of the respondents was 55 years (range 89-21 years). The average number of household members of the study area was five. Household members could assisted with labour, with the respondents indicating a daily average of $6 \mathrm{~h}$ spent on the farm. Respondents indicated working a maximum of $10 \mathrm{~h}$. The minimum time spent on the farm was $1 \mathrm{~h}$ due to most of the respondents farming on communal land, forming groups and employing people to take care of their livestock (farming groups). Despite this, some respondents still visited the farm to check the overall progress of the operations. 
Table 1. Socioeconomic characteristics of the respondents $(n=207)$.

\begin{tabular}{cccc}
\hline & Variables & Frequency & Percentage \\
\hline \multirow{2}{*}{ Gender } & Female & 39 & 18.8 \\
& Male & 168 & 81.2 \\
Marital status & Single & 41 & 19.8 \\
& Married & 139 & 67.1 \\
Main occupation/ & Widowed & 23 & 11.1 \\
Employment & Divorced & 4 & 2.0 \\
& Farmer (full-time) & 144 & 69.6 \\
Secondary occupation/ & Part-time farmers & 63 & 30.4 \\
Outside the farm & Self-employed & 4 & 1.9 \\
& Pensioner & 78 & 37.7 \\
& Unemployed & 62 & 29.9 \\
& Part-time farmers & 63 & 30.5 \\
Funding & Family savings & 104 & 50.2 \\
& Borrowing from others & 5 & 2.4 \\
& Borrowings and other sources & 5 & 2.4 \\
& Family savings and other sources & 4 & 1.9 \\
Other business & Other sources & 89 & 43.1 \\
& No & 170 & 82.1 \\
& Yes & 37 & 17.9 \\
\hline
\end{tabular}

Table 2. Result of statistical analyses of the respondents.

\begin{tabular}{|c|c|c|c|c|c|}
\hline Variable & $\mathbf{N}$ & Minimum & Maximum & Mean & Standard Deviation \\
\hline Age & 207 & 21 & 89 & 55 & 14 \\
\hline Education & 207 & 0 & 16 & 8 & 4 \\
\hline Farming experience & 207 & 1 & 40 & 12 & 8 \\
\hline Hours spent on farm & 207 & 1 & 10 & 6 & 3 \\
\hline Remittances (ZAR) & 207 & 120 & 16,000 & 318 & 1305 \\
\hline Value of livestock (ZAR) & 207 & 6600 & $4,095,000$ & 123,791 & 418 \\
\hline Consumption expenditure (ZAR) & 207 & 1200 & 10,716 & 8750 & 4300 \\
\hline Household own production (ZAR) & 207 & 890 & 11,918 & 6144 & 1810 \\
\hline Veterinary cost (ZAR) & 207 & 40 & 4500 & 1116 & 1469 \\
\hline Feed cost (ZAR) & 193 & 100 & 4483 & 2507 & 5200 \\
\hline Drought relief (ZAR) & 207 & 480 & 11,326 & 4468 & 5424 \\
\hline ADRI (agricultural drought resilience index) & 207 & 1 & 7 & 4 & 3 \\
\hline Welfare change $(\mathrm{W})$ & 207 & 4 & 84 & 56 & 14 \\
\hline
\end{tabular}

ZAR is the South African currency. Source: Author's compilation.

The respondents' average number of formal schooling years was approximately eight, with some farmers not receiving any form of formal education. Most of the farmers who received a formal education had 16 years of schooling. The respondents' farming experience ranged from 1 to 40 years, with the average being 12 years. Having more years of farming experience indicated a higher possibility that the farmer had previously experienced agricultural drought. Thus, during periods of drought, the farmer may have tried other methods to survive or used past strategies.

The results show that respondents had remittances with a monthly average of ZAR 317.83 , which contributed to household income. The average value of livestock was ZAR 123,791 with a minimum of ZAR 6600 and a maximum of ZAR 4,095,000. The value of livestock was computed by multiplying the number of animals by the price per animal.

The average monthly consumption expenditure of a farmer's household was ZAR 8750 with a maximum of ZAR 10,716. The households contributed to meeting the consumption needs from their own production from the farm. The results indicate that, on average, a farmer's household contributed ZAR 6144 from their own production. However, it was deduced that own production did not meet the consumption needs of the households. This justified the need for support (e.g., drought relief) to improve the welfare of the 
households. The results further indicate that the average drought relief was ZAR 4468 with a minimum of ZAR 480 and a maximum of ZAR 11,326. It is worth mentioning that not all the households surveyed received the same amount of relief support, and, as such, the farmers' welfare varied. The average cost of feed was found to be ZAR 2507 with a maximum of ZAR 4483.

\subsection{The Impact of Agricultural Drought on Livestock}

Table 3 presents the experience and perception of agricultural drought. All the smallholder livestock farmers experienced agricultural drought that impacted on their livestock production. A total of $54 \%$ of the respondents indicated the duration of drought periods being an entire year, with $27 \%$ stating it lasted between four and six months and $19 \%$ indicated the duration to be one month. About $70 \%$ of the respondents noticed the occurrence of droughts were more frequent, while $18 \%$ did not see any difference and $12 \%$ thought it was less frequent.

Table 3. The agricultural drought, experience and perception of smallholder livestock farmers $(n=207)$.

\begin{tabular}{cccc}
\hline & Variables & Frequency & Percentage \\
\hline \multirow{2}{*}{ Experienced drought } & Yes & 207 & 100 \\
& No & 0 & 0 \\
Duration of drought & Entire year & 112 & 54.1 \\
& Four to six months & 56 & 27.05 \\
Occurrences/intensity & One month & 39 & 18.85 \\
of drought & More frequent & 145 & 70.05 \\
& Did not see any difference & 37 & 17.87 \\
Agricultural drought & Less frequent & 25 & 12.08 \\
& Led to poor animal health & 82 & 39.61 \\
& Led to a loss of livestock & 56 & 27.05 \\
& Sell their livestock for lower price & 21 & 10.15 \\
& A decline in prices & 27 & 13.04 \\
& A loss of livestock and poor & 21 & 10.15 \\
\hline
\end{tabular}

For some respondents (40\%), agricultural drought led to poor animal health. Some farming households could have afforded to buy the needed medicine during dry periods, but it was not the case for all farmers. For almost $27 \%$ of the respondents, agricultural drought led to a loss of livestock, while $10 \%$ indicated they had to sell their livestock for a lower price. Furthermore, $13 \%$ of the respondents indicated that agricultural drought led to loss of livestock, poor animal health and a decline in prices, while $10 \%$ experienced a loss of livestock and poor animal health.

\subsection{Agricultural Drought Resilience of Smallholder Farmers}

The average ADRI was 4 with a minimum of 1 and a maximum of 7 (see Table 2). This indicated that, generally, the respondents were moderately resilient. To further understand the dimensions of the agricultural drought resilience of the respondents, we disaggregated the resilience according to the different capitals, as presented in Figure 3. The results show that the respondents' social resilience capital with an index of 4.40 was the highest compared to other capitals. The social capital index was computed from the indicators family support, cooperatives membership, membership of farmer association, stokvels and informal saving schemes and connections. 




Figure 3. Resilience capitals of the respondents. Source: Author's compilation.

The economic resilience capital was the second highest, suggesting that the farmers had good production resources and assets that could have helped them absorb climatic shocks. The economic capital index was computed from non-agricultural assets (trucks, television, radio, etc.), agricultural assets (e.g., tractors, hand hoes and implements), credit, savings, remittances, income, value of livestock and crops. Thirty-eight per cent of respondents owned tractors, $42 \%$ owned pigs, $55 \%$ owned chickens and $57 \%$ owned small hand farm implements such ploughs, harrows and hand hoes. Respondents indicated that they sold chickens during the agricultural drought season. Some of the farmers $(26 \%)$ produced crops in addition to livestock. The types of crops produced included fruit (mostly citrus), vegetables and grains. The crops were all used for household consumption. The third-highest resilience capital was related to human resources available to the farmers with an index of 3.13. The human capital was computed from age, education, agricultural skills, farming experience, household members that could assist on the farm and knowledge of drought. The lowest resilience capital was related to natural resources with an index of 2.90, which suggested that the livestock farmers were vulnerable when it came to natural resources. The natural capital was computed considering access to water, pasture access and land ownership. Given that the natural resilience capital was low, we discuss some natural resources of the farmers in detail in the next section.

\subsection{Natural Resources Available to Smallholder Livestock Farmers}

\subsubsection{Land Tenure}

To understand why the respondents had low natural resilience capital, it was necessary to have a clear picture of access to resources such as land and water. Table 4 shows the natural resources (land and water) available to smallholder farmers. Most of the respondents $(52 \%)$ indicated that they used communal land for farming, which belonged to the government. As a result of not owning the land, they did not have access or full property rights, and thus they had difficulty accessing credit. Twenty-six per cent of respondents rented their farms. Furthermore, respondents mentioned customary use (20\%), where farmers farmed on 1 ha (backyard farming) while still producing good quality livestock for the market. Only six respondents $(2 \%)$ owned their farmland, indicating that smallholder farmers lacked resources, but they could still produce an adequate number of livestock. For livestock production, natural grazing played a vital role, which evidently required more land. A possible solution is government intervention to assist smallholder farmers, subsequently enabling them to grow. 
Table 4. Natural resources available to smallholder farmers $(n=207)$.



\subsubsection{Access to Water}

Water remains an essential resource for farming. More than half (57\%) of the respondents did not reside near a river. Although $43 \%$ indicated being close to a river, they were unable to access the water due to not having water rights. Overall, $201(98 \%)$ respondents stated that they had access to other water sources, with four $(2 \%)$ having no access. Boreholes (49\%) were the main source of water supply on most farms. Despite respondents having access to boreholes, not all of the farms' boreholes were operational. Respondents indicated that they sometimes had to take water from their households to the farm, resulting in extra production costs (petrol used for transporting the water). In addition to boreholes, extra water sources included taps or canals (30\%). Respondents who used taps farmed on 1 ha (also known as backyard farming), with canals located on communal lands. Other water sources included wells $(18 \%)$, lakes $(1 \%)$ and none $(2 \%)$ (Table 4). Figure 4 depicts water sources used by respondents for their livestock in the study area.

\subsection{Empirical Results of the Impact of Agricultural Drought Resilience on Smallholder Farmer Welfare}

The average welfare change for the respondents was $56 \%$, with a minimum of $4 \%$ and a maximum of $84 \%$ (see Table 2). This implied that the welfare change of the smallholder farmers was more than average. Table 5 presents the results of factors that influenced the welfare change of respondents. The drought relief variable, as expected, was positive and significant at a $10 \%$ level of confidence. This implied that the drought relief given to farmers contributed to improving the smallholder farmers' welfare.

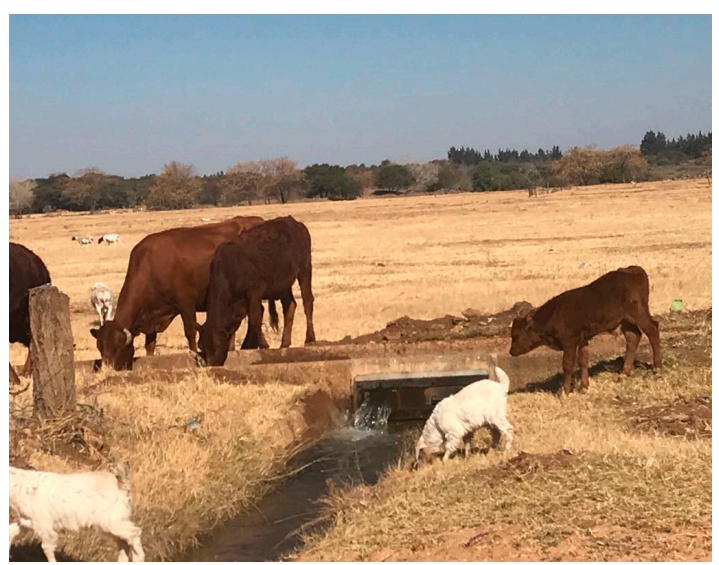

(a) Canals

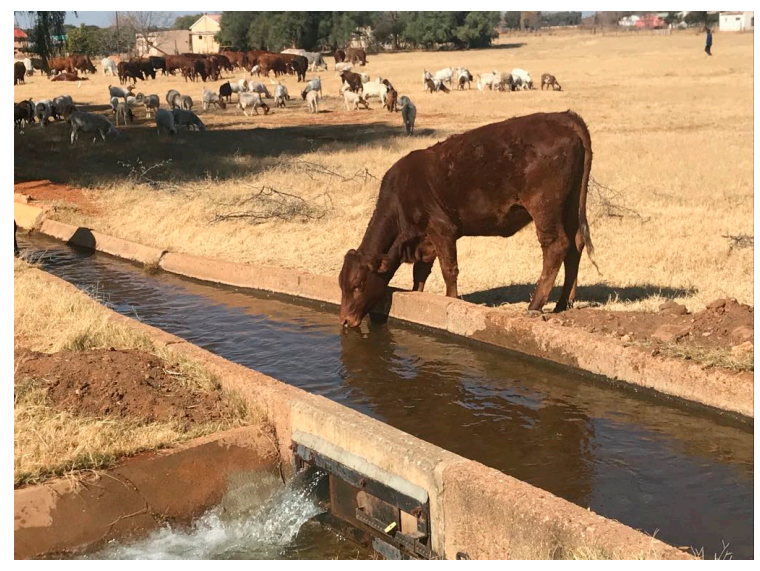

(b) Canals

Figure 4. Cont. 




(c) Wells

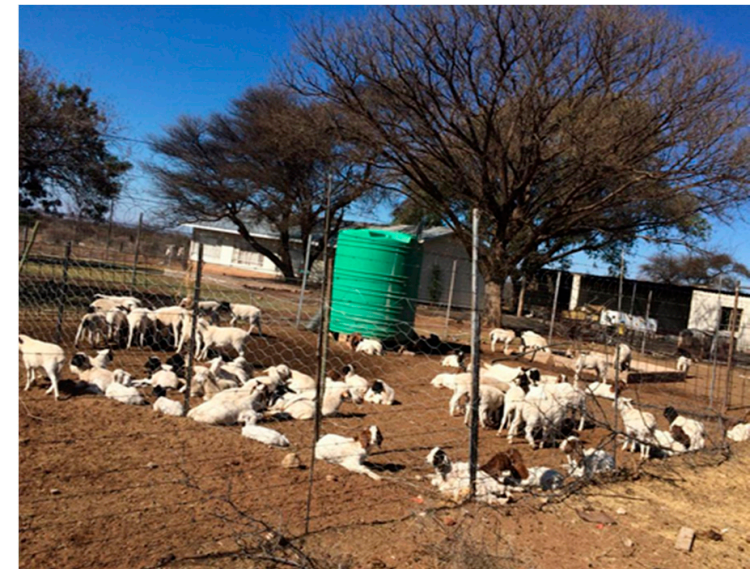

(d) Boreholes

Figure 4. Respondents' water sources from: canals (a,b); wells (c); and boreholes (d). Source: Author's photos.

Table 5. Effects of drought relief and agricultural drought resilience on respondents' welfare.

\begin{tabular}{|c|c|c|c|c|c|c|}
\hline \multirow[b]{2}{*}{ Variable } & \multicolumn{2}{|c|}{ Pooled Sample $(\mathrm{n}=207)$} & \multicolumn{2}{|c|}{ Males $(n=168)$} & \multicolumn{2}{|c|}{ Females $(n=39)$} \\
\hline & $\begin{array}{l}\text { Coefficient } \\
\text { (Robust SE) }\end{array}$ & t-Values & $\begin{array}{c}\text { Coefficient } \\
\text { (Robust SE) }\end{array}$ & t-Values & $\begin{array}{c}\text { Coefficient } \\
\text { (Robust SE) }\end{array}$ & $\mathrm{t}$-Values \\
\hline Gender & $\begin{array}{l}0.1827^{* *} \\
(0.0871)\end{array}$ & 2.09 & - & - & - & - \\
\hline Human capital (HC) & $\begin{array}{c}0.9470 * * * \\
(0.1392)\end{array}$ & 6.81 & $\begin{array}{c}0.9559 * * * \\
(0.1732)\end{array}$ & 5.52 & $\begin{array}{c}0.9277^{* * *} \\
(0.19320\end{array}$ & 4.80 \\
\hline Social capital (SC) & $\begin{array}{c}0.9513^{* * *} \\
(0.1441)\end{array}$ & 6.60 & $\begin{array}{c}0.8567^{* * *} \\
(0.1185)\end{array}$ & 7.23 & $\begin{array}{l}1.0437^{* * *} \\
(0.2396)\end{array}$ & 4.36 \\
\hline Economic capital (EC) & $\begin{array}{l}1.1057^{* * *} \\
(0.1446)\end{array}$ & 7.65 & $\begin{array}{l}1.0510^{* * *} \\
(0.1134)\end{array}$ & 9.27 & $\begin{array}{l}1.2184^{* * *} \\
(0.26130)\end{array}$ & 4.66 \\
\hline Natural capital (NC) & $\begin{array}{c}0.7286^{* * *} \\
(0.1296)\end{array}$ & 5.62 & $\begin{array}{c}0.8625^{* * *} \\
(0.1629)\end{array}$ & 5.30 & $\begin{array}{l}0.5647^{* * *} \\
(0.20679)\end{array}$ & 2.73 \\
\hline Drought relief (DR) & $\begin{array}{l}0.0189 * \\
(0.0299)\end{array}$ & 1.85 & $\begin{array}{l}0.1197^{*} \\
(0.0618)\end{array}$ & 1.94 & $\begin{array}{c}-0.0951^{* * *} \\
(0.0138)\end{array}$ & -6.89 \\
\hline Constant & $\begin{array}{l}1.2535^{* * *} \\
(0.4556)\end{array}$ & 2.75 & $\begin{array}{l}0.2269 * \\
(0.7172)\end{array}$ & 1.71 & $\begin{array}{l}1.0928 * \\
(0.5594)\end{array}$ & 1.95 \\
\hline F-statistic & \multicolumn{2}{|c|}{$216.63^{* * *}$} & \multicolumn{2}{|c|}{$2224.91^{* * *}$} & \multicolumn{2}{|c|}{$148.41^{* * *}$} \\
\hline $\mathrm{R}^{2}$ & \multicolumn{2}{|c|}{0.77} & \multicolumn{2}{|c|}{0.85} & \multicolumn{2}{|c|}{0.72} \\
\hline Adjusted $\mathrm{R}^{2}$ & \multicolumn{2}{|c|}{0.75} & \multicolumn{2}{|c|}{0.83} & \multicolumn{2}{|c|}{0.70} \\
\hline Root MSE & \multicolumn{2}{|c|}{1.804} & \multicolumn{2}{|c|}{1.452} & \multicolumn{2}{|c|}{2.040} \\
\hline Mean VIF & \multicolumn{2}{|c|}{1.75} & \multicolumn{2}{|c|}{1.91} & \multicolumn{2}{|c|}{1.97} \\
\hline
\end{tabular}

*** significant at the $1 \%$ level; ${ }^{* *}$ significant at the $5 \%$ level; * significant at the $10 \%$.

In terms of the agricultural drought resilience capitals, the results indicate that economic resilience capital had the highest significant positive effect on the welfare of smallholder farmers. This was indicated by the highly significant coefficient of 1.1057 at a $1 \%$ level of confidence. The second-highest resilience capital was the social capital of smallholder farmers, as shown by the significant and positive coefficient of 0.9513 . Human capital was the third-highest resilience capital with a significantly positive coefficient of 0.9470. Finally, the lowest resilience capital was natural resource capital with a significantly positive coefficient of 0.7286 .

The gender variable in the pool model was positive and significant at a $5 \%$ level of significance, suggesting that males were more likely to have high welfare improvement relative to females. Given that there were gender disparities, we estimated a separate model for males and females to examine how the results differed. Seventy-five per cent of the variation in welfare changes among the smallholder farmers were explained by 
the explanatory resilience capitals, drought relief and gender, as shown by the adjusted coefficient of determination (Table 5).

The results for males and females indicate that all the resilient capitals were positive and significantly different from zero at a $1 \%$ level. However, the results show that the drought relief variable was positive and significant at a $10 \%$ level, whereas the same variable was negative and significant for females. For males, the results of modelling indicate that the four capitals and drought relief explained $83 \%$ of the variation in welfare, whereas the four capitals and drought relief explained $70 \%$ of the variation in welfare of females. The VIF statistics for all the models indicate that there was no multicollinearity problem in our analysis. In addition, the significant F-statistic for all the models indicate that the joint effects of the variables are significant.

\section{Discussion}

The study revealed that about $56 \%$ of the smallholder farmers' welfare changed due to drought and warranted the government's drought relief. However, as in many developing countries, the study revealed that the amount of drought relief given to farmers was not enough to restore the farmers to their welfare state before the climatic shock. This finding is supported by those of Jordan [21], Mdungela et al. [22], Ncube [45] and Bahta [46] in their studies in the Northern Cape, Eastern Cape, Limpopo and Western Cape provinces of South Africa. They found that drought relief support from governments, especially those in developing countries, are not enough. In addition, the little support usually reaches the farmers late.

The next finding worth discussing is that smallholder farmers' own livelihood capitals played a significant role in improving their resilience and welfare. The study identified four key capitals that define the agricultural drought resilience level of smallholder farmers and their welfare gains. These capitals consisted of human capital, social capital, economic capital and natural capital. These capitals were consistent with the Sustainable Livelihood Frame by DFID [26], Keil et al. [15] and O'Mahony and Samek [42].

The study found that the smallholder farmers were to some extent resilient to agricultural drought. It was revealed that the level of resilience varied according to how the smallholder farmer was endowed with human, social, economic and natural capitals. The study showed that smallholder farmers had high social capital. This demonstrated that smallholder farmers had strong social networks, such as farmers' associations, agricultural departments, families and friends, which offered support in times of drought. Community-based farmers' groups including stokvels and informal saving schemes are important social networks. The second- and third-highest capitals related to economics and human resources.

The livestock farmers had low natural resource endowments and hence had low natural resilience capital. This was not surprising considering that most livestock farmers did not have access to reliable water, land and pastures, particularly in a time of drought. This finding is in line with the study by Maltou and Bahta [6], who found that only $9 \%$ of the smallholder livestock farmers in their study were resilient to agricultural drought. They found farming households with access to credit and training and farmers who are part of a co-operative proved to be more resilient to agricultural drought than those who have no access to these variables.

The strength of the livelihood capitals in enhancing the resilience of smallholder farmers in this study for the Northern Cape Province differed from what Muthelo et al. [47] found for smallholder livestock farmers in the Free State Province of South Africa. They found Free State province of South Africa smallholder farmers have high economic resilience capital followed by social, natural and human capitals. The differences in resource endowment and capitals across provinces provide a rationale for the assessment of resilience and welfare of smallholder farmers in different provinces.

Another important finding from our empirical results is that the four capitals defining agricultural drought resilience had positive impacts on the welfare improvement of 
smallholder livestock farmers in the study area. Specifically, smallholder farmers' welfare was highly influenced by the economic resources available to the farmer, as indicated by the highly significant estimate of economic capital. This is consistent with the finding of Muthelo et al. [47] in the Free State Province of South Africa. Another important capital with a high effect on welfare of smallholder farmers was social capital. The third important capital that improved the welfare of smallholder livestock farmers was the human resource capital available to farmers. Although the natural resource capital available to the smallholder farmers was low, it still had a positive effect on their welfare improvement. Other studies have incorporated these capitals as explanatory variables for smallholder farmers' choices of climate change adaptation strategies [11,20,47,48].

Besides the resilience capitals, the findings further indicate that drought relief and support from government worked to improve the welfare of smallholder farmers in the study area, particularly males. This was consistent with the finding of Sikwela and Mushunje [49], who indicated that farmers' support programmes in Eastern Cape and KwaZulu Natal province of South Africa have a significant and positive impact on smallholders' farmer welfare. Our findings point out gender disparities in terms of impacts of drought relief, with females having low welfare improvements from drought relief compared with males. We therefore suggest that particular attention should be paid to how the drought relief support is distributed across the gender categories. The summary statistics from our data show that males on average received greater relief support than females. Specifically, the government should develop the drought relief support programme in such a way that there will be gender equality in the delivery of assistance. This concurs with the South African Government's recommendation for any government programme to consider gender equality. This would ensure that women are not marginalised when planning developmental initiatives and programmes [50].

\section{Conclusions}

This study examined the welfare of smallholder livestock farming households and how agricultural drought relief support from government and farmers' own resource endowment influenced their welfare. The study was conducted in Frances Baard District Municipality in the Northern Cape Province of South Africa using survey data from 207 livestock farmers. Based on the study findings, the following conclusions were made. Firstly, smallholder farmers who received drought relief support saw an improvement in their welfare. However, the welfare improvements varied across respondents and gender categories, with males gaining welfare improvement and females experiencing welfare loss. Secondly, economic capital, social capital, human capital and natural capital substantially affected the welfare of smallholder farmers. Thirdly, smallholder farmers had a high social resilience index and a low natural resilience capital. Finally, the four resilient capitals identified have higher impacts on welfare change than drought relief. Some policy implications can be drawn from the above conclusions. Our findings imply that drought relief support from governments in times of drought helps to improve the welfare of smallholder farmers. Nevertheless, this study indicates that relying solely on drought relief support is not enough to help smallholder farmers bounce back from drought shock and to improve their welfare. Agricultural policies should be directed towards assisting and encouraging smallholder livestock farmers to building the social networks of smallholder farmers and strengthen existing networks. Another implication is that there a need to develop the economic resource endowment and human resource bases of smallholder farmers. Specific farm management policies should focus on offering smallholder livestock farmers economic and financial management training and education. This can be achieved by equipping extension agents with economic and financial education, which can be transferred to the smallholder farmers. This can also be attained by organising workshops or seminars where smallholder farmers are given training on economic and financial management. In this way, the smallholder farmers can improve their farm economic performance, which will lead to the development of high economic capital. These policies 
can help smallholder farmers be more resilient and better able to improve their standard of living.

Generally, our findings indicate that governments and non-governmental policymakers aiming at improving the welfare of smallholder farmers should focus on building the social, economic and human capital resource bases of smallholder livestock farmers.

This study is unique and adds to existing knowledge as one the first studies to incorporate reliance capitals as explanators of smallholder farmers' welfare. The inclusion of the capitals as explanators provides relevant insights for efficient and sustainable policy design. We recommend that future research should incorporate resilient livelihood capitals as explanators when examining determinants of smallholder farmers' welfare in developing countries, rather than relying on traditional socioeconomic characteristics.

Author Contributions: All authors made a significant contribution to the present manuscript preparation. R.M. was involved in conceptualisation and data collection. Y.T.B. and E.O.-S. performed the data analysis and contributed to drafting the article. Y.T.B. and H.J. were supervisors and collaborators of this project, aided in the study design and policy implications. All authors have read and agreed to the published version of the manuscript.

Funding: National Research Foundation (NRF) of South Africa funded this research, grant number TTK170510230380.

Data Availability Statement: Data are available upon request from the corresponding author, [Y.T.B].

Acknowledgments: We acknowledge and thank the anonymous reviewers for their valuable comments and suggestions. We acknowledge Liesl van der Westhuizen (Science Writer) for language editing this manuscript.

Conflicts of Interest: The authors declare no conflict of interest.

\section{References}

1. Thornton, P.K. Livestock production: Recent trends, future prospects. Philos. Trans. R. Soc. B Biol. Sci. 2010, 365, 2853-2867. [CrossRef]

2. Food and Agricultural Organization of the United Nations (FAO). UN Lays Foundations for More Drought Resilient Societies: Meeting Urges Disaster Risk Reduction Instead of Crisis Management; FAO: Rome, Italy, 2013.

3. Wilhite, D.A.; Sivakumar, M.V.K.; Pulwarty, R. Managing drought risk in a changing climate: The role of National Drought Policy. Weather Clim. Extrem. 2014, 3, 4-13. [CrossRef]

4. Udmale, P.; Ichikawa, Y.; Manandhar, S.; Ishidaira, H.; Kiem, A.S. Farmers' perception of drought impacts, local adaptation, and administrative mitigation measures in Maharashtra State, India. Int. J. Disast. Risk Reduct. 2014, 10, 250-269. [CrossRef]

5. Rojas-Downing, M.M.; Nejadhashemi, A.P.; Harrigan, T.; Woznicki, S.A. Climate change and livestock: Impacts, adaptation, and Mitigation. Clim. Risk Manag. 2017, 16, 145-163. [CrossRef]

6. Matlou, R.C.; Bahta, Y.T. Factors influencing the resilience of smallholder livestock farmers to agricultural drought in South Africa: Implication for adaptive capabilities. J. Disaster Risk Stud. 2019, 11, a805. [CrossRef]

7. Food and Agricultural Organization of the United Nations (FAO). Southern Africa一Situation Report October 2016; FAO: Rome, Italy, 2016.

8. Sithole, V.B. El Nino Impacts in Southern Africa: Highlights from the 2015/16 Season; Paper Presented at the Southern Africa Regional Climate Services Workshop (29 November to 2 December 2016); Global Framework for Climate Services Office: Harare, Zimbabwe, 2016.

9. Agricultural Organizations in South Africa (Agri SA). A Raindrop in the Drought; Report to the Multi-Stakeholder Task on the Drought; Agri SA's Status Report on the Current Drought Crises; AGRI: Pretoria, South Africa, 2016.

10. Department of Agriculture, Forestry, and Fisheries (DAFF). A Framework for the Development of Smallholder Farmers through Cooperative Development; Department of Agriculture, Forestry and Fisheries, Republic of South Africa: Pretoria, South Africa, 2012.

11. Mpandeli, S.; Maponya, P. Constraints and challenges facing the smallscale farmers in Limpopo province, South Africa. J. Agric. Sci. 2014, 6, 135-143. [CrossRef]

12. Khoza, T.M.; Senyolo, G.M.; Mmbengwa, V.M.; Soundy, P. Socio-economic factors influencing smallholder farmers' decision to participate in agro-processing industry in Gauteng province, South Africa. Cogent Soc. Sci. 2019, 5, 1664193. [CrossRef]

13. Callo-Concha, D.; Ewert, F. Using the concepts of resilience, vulnerability and adaptability for the assessment and analysis of agricultural systems. Chang. Adapt. Socioecol. Syst. 2014, 1, 1-11. [CrossRef]

14. Reyers, B.; Moore, M.L. Opinion/We All Want to be Resilient. Or Do We? 2017. Available online: https://rethink.earth/we-allwant-to-be-resilient-or-do-we/ (accessed on 10 April 2021). 
15. Keil, A.; Zeller, M.; Wida, A.; Sanim, B.; Birner, R. What determines farmers' resilience towards ENSO-related drought? An empirical assessment in Central Sulawesi, Indonesia. Clim. Chang. 2008, 86, 291-308. [CrossRef]

16. Lokosang, L.; Ramroop, S.; Zewotir, T. Indexing household resilience to food insecurity shocks: The case of South Sudan. Agrekon 2014, 53, 137-159. [CrossRef]

17. Gwaka, L.; Dubihlela, J. The Resilience of Smallholder Livestock Farmers in Sub-Saharan Africa and the Risks Imbedded in Rural Livestock Systems. Agriculture 2020, 10, 270. [CrossRef]

18. Banda, T.F.; Phiri, M.A.R.; Mapemba, L.D.; Maonga, B.B. Household Resilience to Drought: The Case Study of Salima District in Malawi; IFPRI Working Paper No. 14; International Food Policy Research Institute (IFPRI): Washington, DC, USA, 2016.

19. Vetter, S. Drought, change, and resilience in South Africa's arid and semi-arid rangelands. S. Afr. J. Sci. 2009, 105, 29-33. [CrossRef]

20. Sallu, S.M.; Twyman, C.; Stringer, L.C. Resilient or Vulnerable Livelihoods? Assessing Livelihoods Dynamics and Trajectories in Rural Botswana. Ecol. Soc. 2010, 15, 3. [CrossRef]

21. Jordaan, A.J. Drought Risk Assessment for Extensive Farming in the Northern Cape Province. Ph.D. Thesis, University of the Free State, Bloemfontein, South Africa, 2012.

22. Mdungela, N.M.; Bahta, Y.T.; Jordaan, A.J. Farmer's choice of Drought coping strategies to Sustain Productivity in The Eastern Cape Province of South Africa. Ser. Front. Sustain. 2017, 1, 73-89. [CrossRef]

23. Frances Baard Municipal District Municipality (FBDM). Frances Baard Municipal District in the Northern Cape. Kimberly, South Africa. 2019. Available online: https:/ / municipalities.co.za/map/134/frances-baard-district-municipality (accessed on 18 May 2021).

24. Statistics South Africa (Stats SA). Community Survey 2016: Provincial Profile Northern Cape; Report No. 03-01-14; Statistics South Africa: Pretoria, South Africa, 2016.

25. Department of Agriculture, Forestry and Fisheries (DAFF). Drought Status in the Agriculture Sector. Portfolio Committee on Water and Sanitation; DAFF: Pretoria, South Africa, 2018.

26. Department of International Development (DFID). The Sustainable Livelihood Guidance Sheets; DFID: London, UK, 1999.

27. Morse, S.; McNamara, N.; Acholo, M. Sustainable Livelihood Approach: A Critical Analysis of Theory and Practice; Geographical Paper No. 189; Springer: Berlin/Heidelberg, Germany, 2009.

28. Farrington, J.; Carney, D.; Ashley, C.; Turton, C. Sustainable Livelihoods in Practice: Early Application of Concepts in Rural Areas; Overseas Development Institute: London, UK, 1999.

29. Scoones, I. Sustainable Rural Livelihoods: A Framework for Analysis; Working Paper 72; Institute for Development Studies: Brighton, UK, 1998.

30. Bahta, Y.T.; Strydom, D.B.; Donkor, E. Microcredit and gender empowerment: Policy implications for sustainable agricultural development in Eritrea. Dev. Pract. 2017, 27, 90-102. [CrossRef]

31. Organisation for Economic Cooperation and Development (OECD). Human Capital Investment. An International Comparison; Centre Français d'Exploitation du Droit de Copie (CFC): Paris, France, 1998.

32. Woolcock, M. The place of social capital in understanding social and economic outcomes. Can. J. Policy Res. 2001, 2, 11-17.

33. The High Level Panel of Experts on Food Security and Nutrition (HLPE). Investing in Smallholder Agriculture for Food Security; HLPE: Rome, Italy, 2013.

34. Hecke, B.V. Defining and Measuring Resilience of Smallholder Farm Household in Tanzania. Master's Thesis, Ghent University, Ghent, Belgium, 2018.

35. Maré, F.; Bahta, Y.T.; Van Niekerk, W. The impact of commercial livestock farmers in South Africa. Dev. Pract. 2018, 28, 884-898. [CrossRef]

36. Tandwa, L. Drought Crisis: 3 Provinces Declared National Disasters. 2018. Available online: https://www.news24.com/ SouthAfrica/News/drought-crisis-3-provinces-declared-national-disasters-20180213 (accessed on 11 April 2021).

37. Northern Cape Department of Agriculture, Forestry, and Fisheries (NDAFF). Beneficiaries of an Agricultural Drought Relief Program; NDAFF: Kimberly, South Africa, 2018.

38. Cochran, W.G. Sampling Techniques, 3rd ed.; John Wiley and Sons: Hoboken, NJ, USA, 1997.

39. Bartlett, J.E.; Kotrlik, J.W.; Higgins, C.C. Organizational research: Determining the appropriate sample size in survey research. Inf. Technol. Learn. Perform. J. 2001, 19, 43-50.

40. Walsh-Dilley, M.; Wolford, W.; McCarthy, J. Rights for Resilience: Bringing Power, Rights and Agency into the Resilience Framework; Oxfam International: Washington, DC, USA, 2013.

41. Cutter, S.L.; Barnes, L.; Berry, M.; Burton, C.; Evans, E.; Tate, E.; Webb, J. A place-based model for understanding community resilience to natural disasters. Glob. Environ. Chang. 2008, 18, 598-606. [CrossRef]

42. O'Mahony, M.; Samek, L. Health and Human Capital. In Proceedings of the 34th IARIW General Conference International Association for Research in Income and Wealth General Conference, Dresden, Germany, 21-27 August 2016.

43. Zezza, A.; Davis, B.; Azzarri, C.; Covarrubias, K.; Tasciotti, L.; Anriquez, G. The Impact of Rising Food Prices on the Poor; ESA Working Paper No. 08-07; Agricultural Development Economics Division, The Food and Agricultural Organization of the United Nations: Rome, Italy, 2008.

44. Gadisi, M.; Owusu-Sekyere, E.; Ogundeji, A.A. Impact of government support programmes on household welfare in the Limpopo province of South Africa. Dev. S. Afr. 2020, 37, 937-952. [CrossRef] 
45. Ncube, B. Smallholder Farmer Drought Coping and Adaptation Strategies in Limpopo and Western Cape Provinces; Report for Water Research Commission (WRC), No. 2716/1/20; WRC: Pretoria, South Africa, 2020.

46. Bahta, Y.T. Smallholder livestock farmers coping and adaptation strategies to agricultural drought. AIMS Agric. Food 2020, 5, 964-982. [CrossRef]

47. Muthelo, D.; Owusu-Sekyere, E.; Ogundeji, A.A. Smallholder Farmers' Adaptation to Drought: Identifying Effective Adaptive Strategies and Measures. Water 2019, 11, 2069. [CrossRef]

48. Adu, D.T.; Kuwornu, J.K.M.; Anim-Somuahand, H.; Sasaki, N. Application of livelihood vulnerability index in assessing smallholder maize farming households' vulnerability to climate change in Brong-Ahafo region of Ghana. Kasetsart J. Soc. Sci. 2018, 39, 22-32. [CrossRef]

49. Sikwela, M.M.; Mushunje, A. The impact of farmer support programmes on household income and sustainability in smallholder production: A case study of the Eastern Cape and KwaZulu Natal farmers, South Africa. Afr. J. Agric. Res. 2013, 8, $2502-2511$. [CrossRef]

50. Western Cape Government. Women Empowerment and Gender Equality. Policy Discussion Document for the City of Cape Town. South Africa. 2020. Available online: https:/ / www.westerncape.gov.za/text/2004/8/draft_gender_policy_updated_july04.pdf (accessed on 21 May 2021). 